\title{
Photovoltaic Systems Coupled to Solar Heaters of Water
}

\author{
Eliseu Burda ${ }^{1}$ and Roberto Cesar Betini ${ }^{1}$ \\ Av. Sete de Setembro, 3165. Phone : (+55) 41 3310-4792 \\ CEP.: 80230-901 Curitiba - PR - Brasil \\ E-mails: eliseuburda@ hotmail.com / rcbetini@terra.com.br \\ ${ }^{1}$ Academic Department of Electrotechnique - Federal Technological University of Paraná
}

\section{Summary}

This article suggests a photovoltaic system coupled to a solar heater of water. This system will generate electric power and to heat up an amount of water, through piping among the photovoltaic cells. This idea improves the energy efficiency of the system and it can reduce the consumption of energy of families of low income around $30 \%$.

\section{Keywords}

Photovoltaic System, electric power, renewable sources of energy, solar heating.

\section{1 - Introduction}

Due to the exploration of fossil fuels, the environmental impacts are growing more and more. Therefore there is the need of developing alternative sources of renewable energy such as that generated by the photovoltaic cells [3]. The photovoltaic cells have the function of capturing the solar light to transform it in electric power. In our case, the captured solar energy is used to generate electric power and to heat up the water of a system of piping. Heating up the water that will go by this piping, the same returns to the box of water to be used in the dependences of a residence. From this way, there will be a larger use of the electric power in the residence.

\section{2 - Implementation of the System}

The system should be implemented according to Figure 1. The photovoltaic panel will be in an inferior height to the box of water, with an appropriate inclination to the solar radiation.

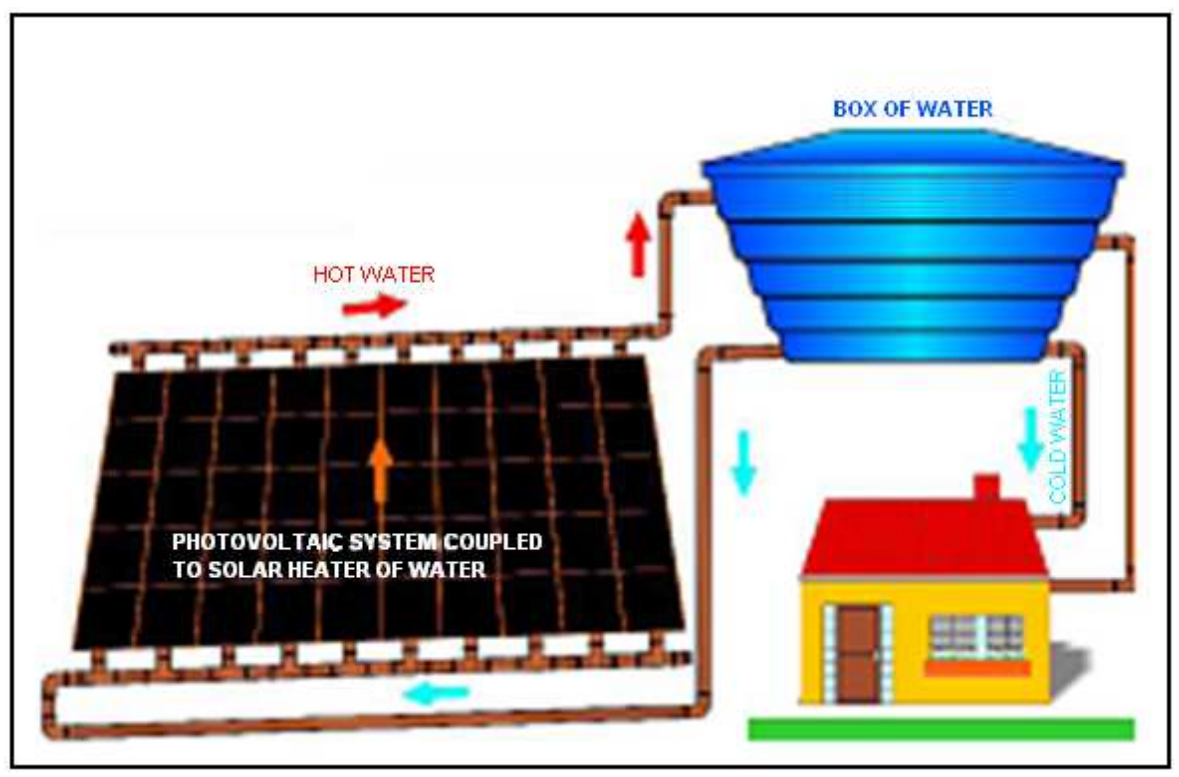

Figure 1:Diagram of the System Operation. 
For convection, the coldest water goes down for the pipes and it enters in the system. With the solar radiation happening in the system, the hottest water arises and it returns to the box of water. The box of water, for it time, possesses two exit pipes for the residence. The pipe in the superior area channels the hot water for the rooms where the hot water is used.

The pipe in the box's inferior area takes the cold water for the rooms where the cold water is used.

This piping of water will pass among the cells of the photovoltaic system, which will be responsible for generating electric power for the residence.

\section{3 - Main Contributions}

This system will contribute to the generation of electric power in a clean and economical way. The expense with electric showers in the residences of the Brazilian families of low income represents $24 \%$ of the total consumption of electric power in the country [4]. The expense regarding the heating of water in the dependences of a residence rotates around $6 \%$ of the total consumption of electric power [4]. Therefore, only the system of solar heating provides an economy of $30 \%$ of electric power. Case came to consider the generation of electric power from the photovoltaic panel, we will see that the system implemented with plates of dimensions of $2960 \times 2720 \mathrm{~mm}^{2}$ gets to supply all of the needs of supply of energy for a family of low income.

\section{4 - Incident Radiation in the System}

We can approximate the system of heating of water to a black body, inserting among the photovoltaic cells, a tube with small holes for the absorption of the radiation. The solar radiation will happen in the tube as shown in Figure 2.

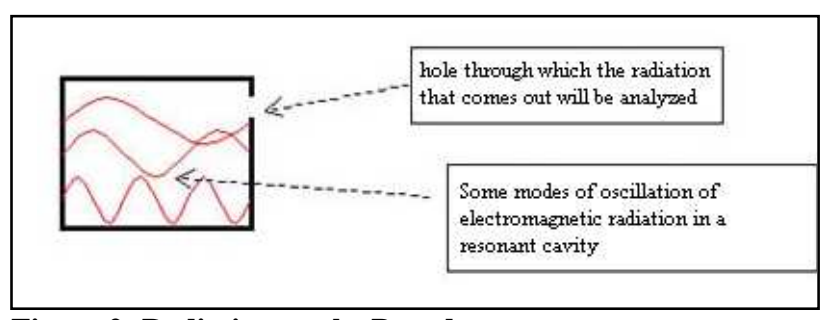

Figure 2: Radiation on the Boards.

The water that comes from the water box will pass for this tube, according to the Figures 3 and 4.

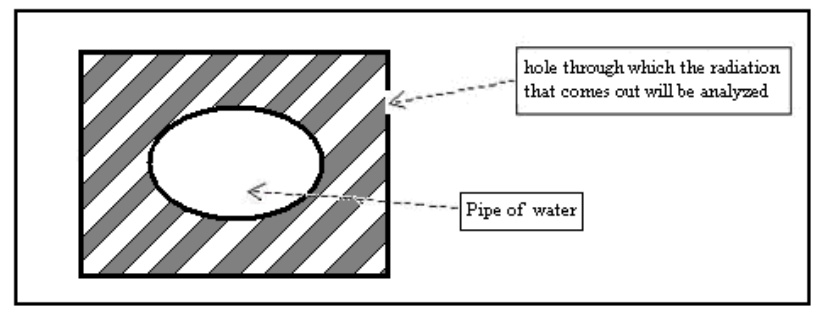

Figure 3 - View in cut of the piping.

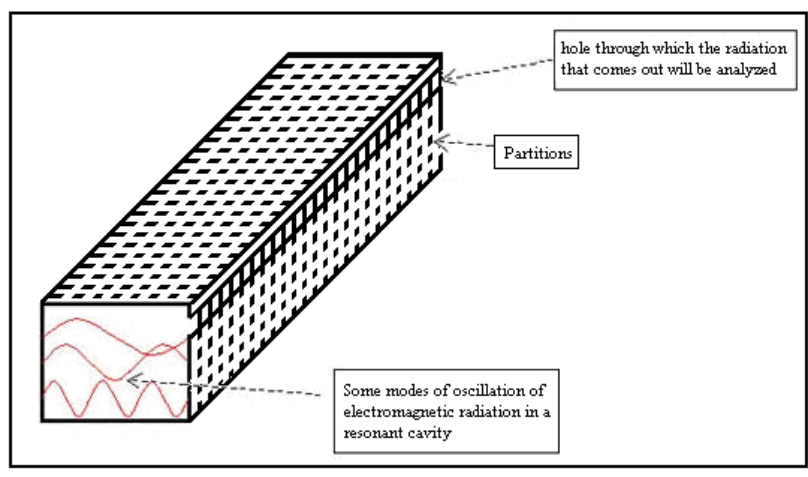

Figure 4 - View in depth of the piping among the photovoltaic plates.

In agreement with Stefan's Law [1], we have:

$$
P=\sigma A e T^{4}
$$

Where: $\mathrm{P}$ - Incident Radiation over the system, in $\mathrm{J} / \mathrm{m}^{2}$; $\sigma-$ Constant of Boltzmann $=1,380622 \times 10^{-23} \mathrm{~J} / \mathrm{K} ; \mathrm{A}-$ Area of the surface, in $\mathrm{m}^{2}$; $\mathrm{e}-$ Emissivity; $\mathrm{T}$ Temperature, in Kelvin.

This radiation that happens on the system will be confined to the piping which will heat up the water that goes by the tubes, in agreement with Stefan's Law [1,2]. According with this law, the solar radiation varies proportionally in agreement with the fourth potency of the temperature, obtaining from this way a good efficiency for the electric power consumption for small residences that possess electric showers.

\section{5 - How to Assemble the System?}

The system will be composed by pipes that they will be involved with metallic tubes, hermetically sealed, that will possess small holes on the superior part of the system, for the entrance of solar radiation and the interior of these metallic tubes will be constituted of several partitions, one for each hole. The photovoltaic system will activate a valve when the water in the box to reach a preset temperature.

Inside of the box of water will be put a thermocouple to detect a preset temperature. When the water inside of the box to reach such temperature, a valve will be worked to impede the entrance of water in the box to avoid its superheat, turning it inappropriate for the consumption. From this way, the system can be linked or turned off, through a valve, which will allow that the hot water enter or not in the system, according to the detected temperature.

The photovoltaic system will have a function of activating the valve of exit of water besides to feed with electric power the residence. 


\section{6 - Photovoltaic System.}

The system is composed by the solar heater of water, as mentioned previously, besides feeding the residence, partly or all of it, with electric power.

The photovoltaic system coupled to a solar heater of water, according to Figure 1, of dimensions 2960 x 2720 $\mathrm{mm}^{2}$, possesses a cost of approximately $\mathrm{R} \$ 6,808.00$ and $520 \mathrm{~W}$ of potency, the an area of, approximately, 8.05 $\mathrm{m}^{2}$, with $16 \%$ of efficiency of the photovoltaic module [5], in other words, to each $1000 \mathrm{~W}$ of radiation happened on the system, the same gets to take advantage of $160 \mathrm{~W}$ of this energy. With base in the nominal potency of the system, it can be defined how many kwatts-hour/day will be necessary to supply the daily consumption of a residence. According to specialists, 2 $\mathrm{kW}$ of nominal potency are necessary to produce 7 $\mathrm{kWh}$ /day in the south area of Brazil [5]. In other words, to each $2 \mathrm{~kW}$ of radiation happened in the system, this is capable to produce $7 \mathrm{kWh}$ for daily use. From this way, this system, with the indicated dimensions above, will produce, on average, $1.82 \mathrm{kWh} /$ day, therefore, 56.42 $\mathrm{kWh}$ monthly, considering one month with 31 days. As the expense with heating of water is about $30 \%$ of the total consumption of electric power in a residence, the proposed system, for a family of low income, can provide a monthly economy of approximately, $100 \%$. Because, in Brazil, a family of low income is composed basically by 4 people and it consumes $80 \mathrm{kWh}$ monthly [6].

\section{7 - Conclusion}

This system of heating of water coupled to a photovoltaic system allows to reduce the electric power consumption supplied by the dealership and to reduce the expenses for families with low income.
In Brazil, a family of low income is composed basically by 4 people and it consumes $80 \mathrm{kWh}$ monthly [6]. The proposed system allows a monthly economy of 80,42 $\mathrm{kWh}$. A family of low income is that that possesses an income monthly inferior to a fourth of the per capita minimum wage [7]. In Brazil, the estimated cost of 1 $\mathrm{kWh}$ is of $\mathrm{R} \$ 0,39$ [8]. Therefore the system proposed in the moment requests 219 months so that the investment pays itself entirely without taking in consideration the possible exemption of taxes for the use of systems no pollutant and generators of renewable energy.

\section{8 - References}

[1] - SERWAY, Raymond A.; JEWETT Jr, John W.; Princípios de Física, vol. 4, $3^{\mathrm{a}}$ ed; 2004.

[2] - Halliday David; Fundamentos de Física, vol. 4, 6 ed; 2003.

[3] - NASCIMENTO, Cássio A.; Princípio de Funcionamento de uma Célula Fotovoltaica (Monografia); Universidade Federal de Lavras; 2004.

[4] - $\quad$ http://www.eletropaulo.com.br/newsletter/ conexao_aeseletropaulo/13/prints/construcao.pdf

[5] - http://www.aondevamos.eng.br/textos/texto02.htm

[6] - http://www.agenciabrasil.gov.br/noticias/2009/12/29/ materia.2009-12-29.4673614573/save_content

[7] - http://www.scielo.br/pdf/rbepop/v23n2/a08v23n2.pdf

[8] - http://www.copel.com/hpcopel/fatura/fatura_grupo_b.html 